\title{
Zarządzanie wartością zdrowia w marketingu na przykładzie wybranych reklam koncernów farmaceutycznych
}

\begin{abstract}
Streszczenie: Przedmiotem artykułu jest kwestia zarządzania wartością zdrowia w marketingu. Autorka podejmuje się analizy problemu w odniesieniu do wybranych reklam koncernów farmaceutycznych, korzystając m.in. z teorii potrzeb. Autorka zwraca uwagę, że ładunek perswazyjny przekazu audiowizualnego w odniesieniu do wyrobów farmaceutycznych wywiera większy wpływ na szczególnego adresata przekazu, jakim jest konsument, którego poziom analizy treści jest obniżony z uwagi na stan chorobowy.

Autorka zauważyła we wnioskach końcowych, że skuteczność kampanii reklamowych zobowiązuje do poszukiwania nowych skutecznych narzędzi oddziaływania. Umiejętność zarządzania wymaga nieustannego analizowania otoczenia, zmieniających się preferencji konsumentów. W ostatnich latach coraz częściej obserwujemy instrumentalne wykorzystanie wartości. Poprzez połączenie z rekomendowanym towarem podnoszą jego atrakcyjność.
\end{abstract}

Słowa kluczowe: wartość zdrowia, reklama, marketing, koncerny farmaceutyczne

\section{Wstęp}

Dodejmując problematykę dotyczącą zaspokajania potrzeb materialnych, które zajmują wiodąca pozycję w działaniach marketingowych, nawiązać należy do teorii potrzeb. Słusznie zauważa J. Galtung, że koncepcja ta, dotyczy funkcjonowania człowieka, w której istotną rolę odgrywają „uprawnienia do takich wartości, które są konieczne dla zaspokajania owych potrzeb" (Galtung, 1994, s. 164). Egzystencja człowieka we współczesnym świecie w obliczu tak silnego oddziaływania kreującej roli mediów, indywidualizuje zachowania i postawy w zakresie poszukiwania nowych ,sposobów na życie”. Pragnienia człowieka w dążeniu do szczęśliwości mają różne oblicze. Jednym z nich jest poczu- 
cie satysfakcji, szczęścia powetowane nabywaniem dóbr materialnych, w tym konsumpcyjnych.

Mimo zachodzących zmian w otoczeniu, wartości społecznie cenione nadal i wciąż, zajmują istotne miejsce w życiu jednostki. Dokonując codziennych wyborów, zwłaszcza pro zakupowych odwołujemy się w sposób zamierzony lub bezwiednie do pewnych zasad, preferencji, które wpływają na podejmowane decyzje. Szczególnie w ostatnich latach zakres stosowania wartości uległ rozszerzeniu. W pierwszej kolejności podkreślić należy, iż są one istotnym, czynnikiem kreowanych działań marketingowych. Nadto, tworzą hierarchiczny układ właściwy dla poszczególnych struktur organizacyjnych w zakresie preferowanych zachowań i postaw.

Renesans wartości jako kryterium wpływającego na decyzje pro zakupowe, zainaugurowany został pod koniec lat 90 -tych XX wieku. Nie tylko w związku z zachodzącymi zmianami w społeczeństwie globalnym, ale także znalazło to potwierdzenie $w$ stanowionych rozwiązaniach normatywnych o wymiarze międzynarodowym, jak i krajowych aktach prawnych. Traktat o Unii europejskiej za fundamentalne wartości przyjmuje ,[...] poszanowania godności osoby ludzkiej, wolności, demokracji, równości, państwa prawnego, jak również poszanowania praw człowieka, w tym praw osób należących do mniejszości. Wartości te są wspólne Państwom Członkowskim w społeczeństwie opartym na pluralizmie, niedyskryminacji, tolerancji, sprawiedliwości, solidarności oraz na równości kobiet i mężczyzn" (Traktat o Unii Europejskiej, art. 2). Nie może zatem budzić żadnych wątpliwości to, że „zdrowie” jest szczególnego rodzaju dobrem, stanowiącym atrybut jednostki i społeczności. Stąd obowiązek ustawodawców w zakresie opracowania rozwiązań gwarantujących jego ochronę. Powszechna Deklaracja Praw Człowieka (m.in. art. 12, 25), Międzynarodowy Pakt Praw Obywatelskich i Politycznych (art. 16-19), Europejska Konwencja Praw Człowieka (Konwencja o Ochronie Praw Człowieka), Karta Praw Podstawowych (Karta), a w Polsce art. 68 Konstytucji RP (Konstytucja Rzeczypospolitej Polskiej) i akty prawa krajowego m.in. statuują zdrowie jako wartość szczególnie cenioną. Kodeksy etyczne, deontologia zawodowa, zwyczaje, obyczaje stanowią obok rozwiązań normatywnych źródła weryfikacji w zakresie treści spotów reklamowych przez uprawnione do tego struktury organizacyjne (szerzej: Barańska, 2012).

O wartościach możemy mówić nie tylko w odniesieniu do jednostki, grup, społeczeństw, ale również w wymiarze funkcjonowania korporacji, 
przedsiębiorstwa czy instytucji. Zarządzanie jednostką organizacyjną poprzez wartości jest aktualnie nie tylko modne, ale przynosi efekty w zakresie oceny osiaganych zysków.

Celem niniejszej publikacji jest ukazanie instrumentalizacji wartości w marketingu na przykładzie zdrowia i stosowanych rozwiązań w przekazach reklamowych oraz ich wpływu na procesy decyzyjne konsumentów.

Na poszczególnych kartach omówione zostaną zagadnienia dotyczące pojęć podstawowych tj. wartości społecznie cenione i ich rola w marketingu, pojęcie wartości zdrowia/zdrowie. Po omówieniu teoretycznych rozważań zaprezentowana zostanie analiza wybranych reklam wyrobów farmaceutycznych emitowanych w telewizji.

\section{Marketing wartości społecznie cenionych}

Pojmując działania marketingowe, jako system organizacyjnych rozwiązań wpływających na decyzje konsumentów, w których poprzez zastosowanie metod, technik i instrumentów oddziaływania zainteresowany podmiot, zmierza do zwiększenia popytu na oferowany przez niego towar, usługę lub pozytywne kształtowanie wizerunku przedsiębiorstwa czy instytucji. W całym spektrum podejmowanych czynności i stosowanych praktyk, coraz większe znaczenie mają schematy działań opisane w strategiach i misjach. To właśnie w dokumentach zwanych strategią wyznaczane są dążenia i kierunki rozwoju, dla których fundamentem są preferowane wartości społecznie cenione. M. Armstrong stwierdza, że „kulturę przedsiębiorstwa tworzą wspólne przekonania, postawy, wartości, które wpływają na kształt działań i wzajemnych kontaktów międzyludzkich" (Armstrong, 1998, s. 86).

Ustanowione priorytety rozpatrywać należy zarówno w odniesieniu do klientów, jak również relacji, jakie powstają pomiędzy podmiotami $\mathrm{w}$ procesie wymiany towarowo-usługowej. Z punktu widzenia podmiotowego, istotna jest wiedza dotycząca zarówno klientów indywidualnych, jak kontrahentów, grup odniesienia czy partnerów. W nawiązywanych transakcjach, porozumieniach pomiędzy ww. aktorami, za istotne uznać należy powstające związki oraz źródła ich długofalowej, perspektywicznej współpracy. W tym kontekście, często odwołujemy się do takich pojęć, jak marketing wartości klienta czy relacyjny. Adaptacja społecznie cenionych wartości dla potrzeb działalności gospodarczej oraz ich trans- 
krybowanie w celu osiagania zysku, rozgłosu czy pozytywnego wizerunku sprawia, że traktowane są instrumentalnie.

Od początków wymiany towarowo-handlowej, odwoływano się do wartości, posługując się różną argumentacją, techniką zachowań, by osiągnąć zamierzony cel ekonomiczny - sprzedaż produktu, a co za tym idzie osiągnąc zysk. Ewaluowanie stosowanych narzędzi oddziaływań na potencjalnych interesariuszy przyczyniło się do dokonania analizy otoczenia wewnętrznego oraz działających jednostek organizacyjnych, a także preferowanych wartości społecznie cenionych w społeczeństwach, pod kątem opracowania filozofii i kierunków rozwoju instytucji, jak i zrodziło potrzebę nieustannego rozszerzania wiedzy na temat klientów i źródeł dokonywanych wyborów pro zakupowych.

Przyjęty system rozwiązań, wyznacza kierunki działania w codzienności bytu wewnątrz instytucji, a także kierowania do otoczenia informacji o sobie, za pomocą technik i instrumentów oddziaływania. ,[...] symbole, mity, rytuały oraz wartości i normy" (Lucewicz, 2000, s. 39), nie tylko stanowią o filozofii funkcjonowania przedsiębiorstwa, ale narzucają pewne schematy zachowań, konweniując także politykę informacyjną czy imputując czynności podejmowane $\mathrm{w}$ ramach działań marketingowych. Zorientowanie na klienta, podkreśla jego rolę i znaczenie w całym procesie organizacyjnego funkcjonowania, ale również wpływa na przygotowywaną strategię podkreślającą obecności na rynku tak jego wytworów, jak i utrwalania w świadomości nabywców pozytywnego wizerunku. Współcześnie istotne miejsce w strategiach marketingowych zajmuja:

- marketing relacyjny zwany partnerskim,

- marketing wartości.

„Marketing partnerski jest to ciagły proces poszukiwania i tworzenia nowej wartości z indywidualnym klientem oraz dzielenia się korzyściami w ramach układu partnerskiego, obejmujący cały okres aktywności nabywczej klienta. Jego podstawą jest zrozumienie znaczenia współpracy między dostawcami a wybraną grupą klientów w celu tworzenia wspólnej wartości po to, aby następnie się nią podzielić" (Gordon, 2001, s. 35-36). Celem jest opracowanie katalogu wartości klienta zgodnych z jego preferencjami i adresowanych do niego za pośrednictwem stosowanych technik i narzędzi (por. Gordon, 2001; Rogoziński, 2006; Otto, 2001). Nie ulga zatem watpliwości, że wartości mogą kreować model zarządczy organizacji zwłaszcza w kontekście: organizacji, współpracy, konkurencji i konkurencyjności. Zarządzanie poprzez wartości najczęściej oceniane jest z punktu widzenia struktury jednostki, np. stylu pracy oraz adaptowa- 
nia dla potrzeb przedsięwzięć marketingowych (Doyle, 2008). Jednocześnie zaznaczyć należy, że każde społeczeństwo posiada własny system wartości społecznie cenionych, wyznaczających zasady postępowania i zachowania poszczególnych podmiotów.

Próba definicji pojęcia „wartości”, wymaga analizy zjawiska z punktu widzenia: ontologicznego, epistemologicznego, genetycznego, logicznego, lingwistycznego czy ekonomicznego. W naukach społecznych mimo prowadzonego dyskursu, występuje wciąż wiele definicji wartości, jednakże żadna z nich, nie ma jednak charakteru bezwzględnie obowiązującej. Wartość zatem, to termin wieloznaczny - używany w języku potocznym, występuje także w wielu naukach, takich jak filozofia, socjologia, prawo, ekonomia czy psychologia. W związku z tym pytanie, czym są wartości, przynosi różne odpowiedzi uzależnione od dziedziny wiedzy, w ramach której pojęcie to jest analizowane. W. Tatarkiewicz, uważał, że: „Zdefiniowanie wartości jest trudne, jeśli w ogóle możliwe. Wyraz ten bowiem zdaje się oznaczać swoiste, proste, nierozkładalne zjawisko, ein Urphanomen... Podobnie, jak wyraz »byt« czy »świadomość«. To co wygląda na definicję "wartości« jest raczej zastapieniem wyrazu przez inny mniej więcej to samo znaczący, na przykład dobro. Albo jest omówieniem. Omówienie takie ma zwykle jedną z dwuch postaci: mówi, że wartość rzeczy jest tą samą własnością, która czyni, iż lepiej jest by rzecz ta była, niż by nie była, bądź mówi, że wartość jest tą własnością rzeczy, ze względu na którą chcemy tę rzecz mieć, ze względu na którą jest nam ona potrzebna" (Tatarkiewicz, 1976, s. 61-62).

Słusznie zauważa, K. Popielski, że „,[...] wybór wartości, jakimi człowiek chce kierować się w swoim życiu, pozostaje poza jego wyborem indywidualnym, to jednak implikacje tego wyboru obecne są zarówno w życiu społecznym, rodzinnym, jak i zawodowym" (Popielski, 1994).

Szczególnie w ostatnich latach zarządzający przedsiębiorstwami coraz częściej zwracają uwagę na instrumentalizację wartości jako czynniki pozytywnie kreującego oceny przedsiębiorstw na rynku. Zarządzanie przez wartości (Blanchard, O’Connor, 1998; Covey, 1989) nie jest jedynie teoretycznym założeniem, ale odpowiednio dobrana taktyka dowodzi skuteczności takiego wyboru. Poznawanie złożoności uwarunkowań współczesnego homo axilogicus - człowieka, „,którego wartości stanowią rdzeń krystalizujący osobę i nadają kierunek jego działaniu" (Gołaszewska, 1994, s. 93), stanowią ważny czynnik w procesie kreowania polityki działań marketingowych przedsiębiorstwa, w taki sposób by można było wpływać na zakres dokonywanej interpretacji pojęć, jak również wdrażać 
je w ciagg marketingowych kreacji. Humanizacja kierowania przedsiębiorstwa zmierza ku przybliżaniu instytucjonalnych rozwiązań działających na rzecz dobra człowieka. Wartości zatem tworzą kulturę organizacyjną przedsiębiorstwa. Nie dotyczy to li tylko pracowników, ale także otoczenia, w jakim się ono znajduje, jak również to jak na niego wpływa lub pragnie wpływać. Zważywszy, że w procesie nabywania, wartości postrzegane są jako wyznacznik zachowań i działań pro konsumenckich, pobudzający potrzeby i dokonujący ich wartościowania (por. Karney, 1998). Odwołując się do egzystencjonalizmu pozycjonującego jednostkę, jako osobę wolną dokującą wyborów poprzez odwoływanie się do wyznaczonych przez samą siebie kryteriów i uzasadnień. Następstwem braku zaspokojenia dążeń wynikających z egzystencji są frustracje, nerwice, spadek poczucia wartości, brak poczucia celowości i sensu życia. V. E. Frank, K. Popielski uważają, że współczesny egzystencjonalizm człowieka opiera się na koncepcji „noetycznego wymiaru osobowości”, której człowiek dąży ,„kku... « komuś lub czemuś, co stanowi dla niego wartość" (Popielski, 1994), istotną w procesie bytu i związanych z nim wyborów. Wiedza doprecyzowując cel dążenia, stanowi źródło prac dla osób odpowiedzialnych za rozwój i sukces poszczególnych jednostek organizacyjnych. Poznanie wymiarów fizycznego, psychicznego i noetycznego człowieka, pozwala na stosowanie korelacji w doniesieniu do kreowanych planów działań marketingowych. Takie podejście znajduje uzasadnienie w stanowisku prezentowanym przez S. Kowalczyka: ,wartością jest to, co jest przedmiotem pożądania, co jest upragnione przez człowieka, co jest celem jego zabiegów" (Kowalczyk, 1979, s. 464). Materialny wymiar wartości jest konsekwencją przypisania jej poszczególnych właściwości i cech, dzięki czemu, zyskuje wyższy poziom ocen względem konkurencyjnych na rynku przedmiotów. Józef Maria Bocheński uważa, że: „to dzięki czemu dany przedmiot jest wartościowy, nazywa się wartością" (Bocheński, 1992, s. 135). Tak postrzegane wpływają na zachowania ludzi, ukierunkowują ich aspiracje, motywują do działania. Mając na względzie powyższe można przyjąć, że zarządzanie wartością w przedsiębiorstwie polega na opracowaniu rozwiązań i sposobów zachowania w celu maksymalizacji spełnienia oczekiwań, satysfakcji konsumentów. W obliczu zachodzacych zmian w procesie pozyskiwania i utrzymywania klientów, szczególna rola przypada marketingowi.

Słusznie zauważa, że „budowa wartości klienta przez dostarczanie mu wartości (korzyści) musi uwzględniać podejście dynamiczne" (Dobiegała-Korona, 2012, s. 69). 
Znajomość hierarchicznego układu wartości społecznie cenionych nie pozostaje bez wpływu na treść m.in. komunikatów adresowanych do ogółu konsumentów.

Rodzina, praca itp., są linearnie postrzegane w relacjach człowiekprzedsiębiorstwo. Jednomyślność widoczna jest w podejmowanych procesach marketingowego oddziaływania - np. przedsiębiorstwo to jedna wielka rodzina ze wszystkimi konsekwencjami wynikającymi z przyjętego stanowiska. Praca odgrywa istotne znaczenie w życiu człowieka. Poczucie satysfakcji wynikające $\mathrm{z}$ dobrze wypełnionego obowiązku zawodowego, możliwość zaspokajania potrzeb materialnych, a co za tym idzie osiagnięcie statusu społecznego - sprawiają, że oceniamy ją z punktu widzenia kalkulacyjnego (osiaganych korzyści) oraz samorealizacji.

Koherentność transportowana na grunt wizerunkowości jednostki, dotyczy także reklam. Systemów opracowanych znaczeń pozwala na ich stosowanie, nie tylko w kontaktach interpersonalnych, ale i inny formach zachodzących iteracji, co za tym także przekazów reklamowych.

K. Popielski „opisuje jednostkę ludzką ze wskazaniem na jej podmiotowość osobowa, z której wynika możliwość do autodystansowania się, tanscedentowania siebie, zdarzeń, doświadczeń, ale także jej ograniczania" (Popielski, 1994, s. 128). Aktywnie uczestnicząc w procesie oceniania świata, wchodzi w interakcje medialne, obserwując skierowane do odbiorców przekazy telewizyjne. Odbiorca poddaje weryfikacji nie tylko pod względem tematycznym ofertę programową, ale również wnikliwie analizuje przekaz audiowizualny. „Strategie korzystania z telewizji można podzielić ze względu na skutki psychologiczne ich stosowania $[\ldots]$ :

- skutki konstruktywne - służą rozwojowi jednostki ludzkiej i dojrzewaniu jej osobowości poprzez odkuwanie wartości, przyswajanie norm i wzorów zachowań, poszerzanie horyzontów, kształtowanie poglądu na świat,

- strategie destruktywne - moga powodować działania negatywne w psychice użytkowania. Dzieje się to przede wszystkim poprzez wprowadzanie w świadomość człowieka tzw. antywartości. Stosując strategie negatywne w korzystaniu z mediów, odbiorca wzmacnia siłę oddziaływania treści destrukcyjnych w przekazie telewizyjnym" (Owsiak, Popielski, 2008, s. 370).

Akceptując przekazywane treści, człowiek doświadcza wagi ich znaczenia, bowiem dostrzega odzwierciedlenie własnej egzystencji. Jako 
nośnik motywacyjny aktywizują i ukierunkowują ludzkie działania. Siła z jaką oddziałują znajduje swoje ukonstytuowanie na poziomie świadomości i nieświadomości projekcji argumentów decyzyjnych. Transcendencja niematerialnych właściwości dokonuje się w zmaterializowanym obrazie - wpływającym na odczuwanie szczęścia jako konsekwencji nabycia nowego przedmiotu czy faktu dokonania samej transakcji.

Z ekonomicznego punktu widzenia termin wartość można określać sam towar czy usługę. Rodzaj dobra zaopatrzonego w cenę, z której perspektywy odnosimy się do pojęcia wartości. Termin ten z punktu widzenia ekonomicznego inkorporuje następujące rodzaje wartości:

- funkcjonalną,

- społeczna,

- emocjonalną,

- w związku z unikatowością produktu,

- w związku z sytuacją konsumenta.

Wykres 1. Struktura wartości wpływających na proces dokonywania wyboru przez konsumenta

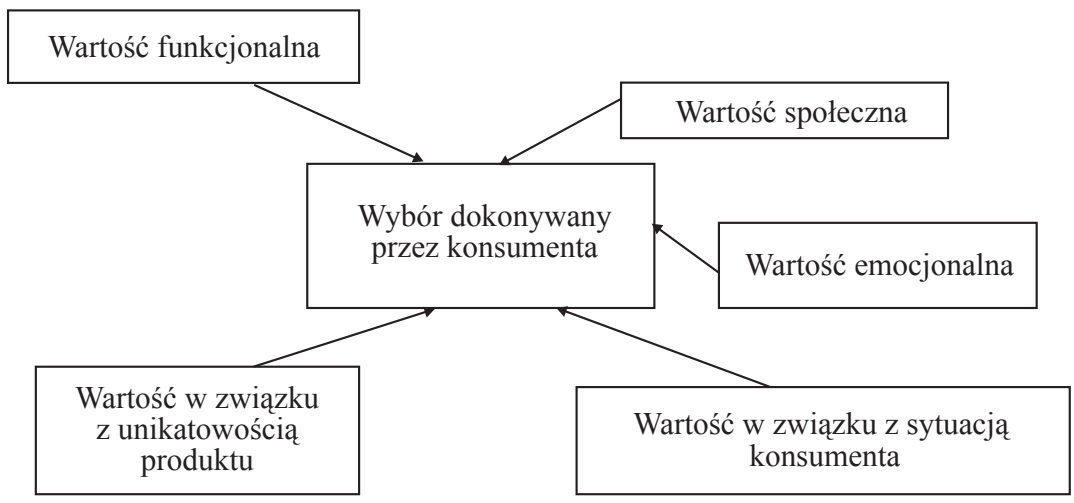

Źródło: S. N. Jagdish, B. A. Newman, B. L. Gross (1991), Consumption Values and Market Choices: Theory and Applications, South - Publishing Co, Cincinnatti.

Niezależnie od tego, która z wymienionych wartości będzie mięć decydujące znaczenie przy dokonanym wyborze, każda wnosi cząstkowy wkład w procesie zakupowym.

„[...] wartość społeczna dotyczy zdolności produktu do tworzenia pozytywnych asocjacji z grupami odniesienia. Wartość emocjonalna łączy się ze zdolnością wywoływania przez ofertę oczekiwanych emocji [...]. 
Wartości związane z sytuacją (conditional values) dotyka takich użyteczności, które mają sens właśnie ze względu na warunki, w których znajduje się konsument [...]. Wreszcie wartości związane z unikatowością produktu odpowiadają oczekiwaniom na coś nowego, niestandardowego, oryginalnego" (Prymon, 2008, s. 166-167). Tak postrzegany produkt będący odpowiednikiem mozaiki wartości go stanowiących w działaniach marketingowych traktowany jest instrumentalnie. To co dla konsumenta jest wartością dającą tzw. customer satisfaction, dla firm stanowi źródło opracowań adoptujących elementy sprawiające zadowolenie. Ekspozycja ich wzbogaca postrzeganie wartości produktu jako takiego, konsumenta wyposaża w katalog preferencji wyboru, zwłaszcza gdy dotyczą podobnych wyrobów. Motywy dotyczące wyboru powodowane mogą być nawykami stanowiącymi kwintesencję naszych doświadczeń lub wartościami przypisanymi przedmiotom przez otoczenie. Przeżycia, doświadczenia zapewne zajmować będą wyższą pozycje przed preferowanymi przez otoczenia, ale gdy dojdzie do zbiegu przepisywanych produktowi z indywidualizowanym systemem wartości, prawdopodobieństwo decyzji zakupowych wzrośnie. Zabiegi związane z instrumentalnym traktowaniem wartości przez przedsiębiorstwa w odniesieniu do sprzedaży powodowane są konkurencyjności na rynku, a także społecznie aprobowanym stanowiskiem, które odrzuca w obliczu posiadanego doświadczenia argumenty ilościowe na rzecz jakościowych. Jakość postrzegana jest przez wartość mającą urealnione znaczenie. Uosobione w przedmiotach mających realny byt stanowią legitymację dla decyzji pro zakupowych konsumentów.

Umiejętne korzystanie dla potrzeb marketingu z katalogu celów i dążeń konsumentów wymaga poznania i opracowania katalogu wartości. W roku 1988 M. J. Muson i E. McQarriego przeprowadzili badania wśród amerykańskich konsumentów dotyczące wartości. Rezultaty badań zaprezentowano jako „fakultatywny zbiór popularnych wartości ostatecznych i instrumentalnych" (por. tabela 1).

Tabela 1

Podział wartości

\begin{tabular}{||l|l||}
\hline \multicolumn{1}{|c|}{ Wartości finalne } & \multicolumn{1}{c|}{ Wartości instrumentalne } \\
\hline \multicolumn{1}{|c||}{} & \multicolumn{1}{c|}{2} \\
\hline Wygodne życie & Ambitność \\
\hline Ekscytujące życie & Wszechstronność \\
\hline Poczucie spełnienia & Zdolność \\
\hline Świat piękna & Urok \\
\hline
\end{tabular}




\begin{tabular}{||l|l||}
\hline \multicolumn{1}{|c||}{1} & \\
\hline Równość & Czystość \\
\hline Bezpieczeństwo rodziny & Wyobraźnia \\
\hline Wolność & Niezależność \\
\hline Szczéście & Zdolności intelektualne \\
\hline Wewnętrzna harmonia & Logika \\
\hline Przyjemność & Odpowiedzialność \\
\hline Samouznanie & Samokontrola \\
\hline Społeczne uznanie & \\
\hline Wiedza & \\
\hline
\end{tabular}

Źródło: M. J. Muson i E. McQarriego, Shortening the Rokeach Value Survey For Use in Consumer Research, „Advances in Consumer Research” 1988, vol. 15, cyt. za M. Prymon, Kategoria wartości w perspektywie nauk menadżerskich, w: K. Popielski, s. 164. Według M. Rokeacha, Wartości instrumentalne służą osiaganiu stanów ostatecznych (Rokeach, 1979).

Wspólnym kryterium wielu strategii jest pojęcie jakości oferty. Jako miernik i element wartościowania produktu jest uwzględniany w procesach decyzyjnych konsumentów. Według D. von Hildebranda można je podzielić na ontyczne i kwalitatywne (jakościowe). Pierwsze dotyczą bytu człowieka, drugie związane są z ocenianiem wynikającym ze skali alternatyw ocennych. Pamiętać należy, iż jako istoty rozumne i wolne sami dokonujemy wyborów w realizacji zamierzeń. W swojej zewnętrznej wolności uprawniony jest także do dokonywania wyborów rzeczy, które jak zauważył E. Kant, mają cenę (Kant, 1972, s. 211).

\section{Jakość jako wartość przedsiębiorstwa}

Wartości cechują każdą kulturę, społeczeństwo. Ich hierarchizacja uwarunkowana jest m.in. historią, geopolitycznym położeniem miejsca, w którym społeczność zamieszkuje, warunkami ekonomicznymi.

Współczesny świat oparty na kulturze konsumpcji niemal gloryfikuje przyjemność relatywizowaną do pojęcia zakupologii - shoppingu. Bogactwo oferty, szybkość dokonujących się w nim przeobrażeń sprawia, że proces starzenia się produktów, chociażby na skutek emitowanych reklam, ukazujących coraz to lepsze, skuteczniejsze, efektywniejsze produkty, pozwala na stwierdzenie, że ,[...] kulturę tę cechuje schizofreniczność, polegająca na ciagłym zwiększaniu szybkości cyklu »nowość« 
- »przestarzałość«. Na skutek tego człowiek żyje w ciagłym »konsumpcyjnym niepokoju «, który staje się stanem normalnym i obowiązującym" (Melosik, 2003, s. 7). Potrzeba nadążania za dokonującymi się zmianami sprawia, że stajemy się coraz bardziej otwarci na przeobrażenia zachodzące w otoczeniu, które w konsekwencji wpływają na zachowania i postawy m.in. potencjalnych konsumentów.

Jak wcześniej podkreślano, menadżerowie poszczególnych struktur organizacyjnych zobowiązani są do systematycznego monitorowania oczekiwań, preferencji nabywców. U podstaw planów działań marketingowych leży m.in. wiedza na temat smaków, poczucia estetyki, potrzeb, mechanizmów perswazyjnego oddziaływania, trendów, mody odbiorców przekazu.

Wskazane czynniki nie tylko wyznaczają płaszczyznę preferowanych działań marketingowych, ale głównie używanych dla skutecznego osiągnięcia celu narzędzi i technik oddziaływania.

Jedna z najstarszych form jest reklama. Etymologiczne uwarunkowania wskazuja, że termin znany był starożytnym Rzymianom. Słowo reclamo reclamare oznacza ogłaszać, krzyczeć (Słownik łacińsko-polski, 1982, s. 421-422). W rzeczy samej komunikat reklamowy skierowany do potencjalnego nabywcy, ma na celu m.in. przekazanie treści o nowej lub zmodyfikowanej ofercie jego nadawcy. Język, humor, gra kolorów, udział osób ich charakteryzacja, mimika twarzy, gesty, m.in. to składać się może na perswazyjność reklamy.

W ostatnich latach zaobserwować można, że coraz częściej scenariusze spotów reklamowych odwołują się do wartości społecznie cenionych, tj. rodzina, zdrowie, praca.

Konstruowanie scenariuszy adaptujących wartości stało się nie tylko modne, ale także skuteczne. Odbiorca szybciej identyfikuje się z reklamowanym bohaterem spotu i zyskuje pozytywne nastawieniem do rekomendowanego produktu, jeżeli dostrzega zgodność preferowanych treści z własnym systemem wartości.

Z tego względu towarzystwa ubezpieczeniowe oferujące polisy, podobnie banki, producenci artykułów konsumpcyjnych często odwołują się do wartości, zdrowia, rodziny. Podejście takie uznać należy za zasadne. Popularyzowanie zdrowego stylu życia, dobrej kondycji zdrowotnej, odpowiedniej pod względem kalorii diety mieści się w zakresie wskazanych wyżej wartości. Charakter przekazu ma zarówno wymiar werbalny, jak i stanowi rezultat odpowiednio skonstruowanej treści wizualnej. 


\section{Wartość zdrowia w reklamach firm farmaceutycznych}

Indyferentność podejść w zakresie definiowania pojęcia zdrowie, mimo upływu czasu nie daje podstaw do wskazania jednej bezwzględnie obowiązującej definicji. W literaturze przedmiotu wyróżniono pojęcie „zdrowia”, jak również kategorii „zdrowie”. Pierwsze z wymienionych jest wartością samą w sobie, dobrostanem jakim dysponuje jednostka. Drugie zaś odnosi się do:

- „wartości odczuwanej - uznawanej przez jednostkę za rzeczywiście cenną, atrakcyjna, pożądana, generującą podstawy emocjonalne i wyzwalającą działania (np. profilaktyczne lecznicze): zależnej od stanu fizjologicznego organizmu (np. uczucie głodu) i stopnia zinternalizowania wpływów społecznych;

- wartości uznawanej - przekonanie jednostki, że zdrowie powinno być cenione, ponieważ postrzegane jest jako cenne w środowisku społecznym; przekonanie to w mniejszym stopniu jest oparte na emocjach, zawiera element powinności i często pozostaje w sferze deklaracji, ale jest trwalsze, bardziej ustabilizowane niż wartości odczuwane" (Barańska, 2013, s. 169-195).

Dbałość o zdrowie stała się wyzwaniem XXI wieku (zob. Zdrowie $i$ zdrowy styl życia $w$ Polsce..., 2007). Nie jest to tylko obowiązek ciążący na jednostce, ale przede wszystkim na instytucjach państwowych i organizacjach, których jednym z zadań jest zagwarantowanie odpowiednich procedur i aparatu gwarantujących bezpieczeństwo zdrowotne. Także przedsiębiorcy dostrzegają konieczność partycypowania w procesie edukacji, profilaktyki zdrowotnej, a także oferowania produktów i usług, które mają ułatwić i pomóc w osiaganiu zamierzonego celu. Jak wynika z badań przeprowadzonych w Polsce w roku 2015, „Niemal wszyscy ocenili, iż zdrowie, rodzina i szczęście rodzinne oraz uczciwość mają dla nich duże znaczenie (w tym bardzo duże)" (Wartości i zaufanie społeczne $w$ Polsce..., 2015, s. 5). Ponad 89\% badanych uznało za najwyżej cenioną wartość - zdrowie (Wartości i zaufanie spoleczne w Polsce..., 2015, s. 6). Wartości same w sobie mogą być chronione przez odpowiednio ukształtowane normy prawne albo pozanormatywne rozwiązania.

\section{Analiza rynku farmaceutycznego}

Wśród podmiotów gospodarczych, szczególne miejsce zajmują producenci wyrobów farmaceutycznych. Dynamika rozwoju tej dziedziny, 
powetowana jest wieloma czynnikami. Jednym z nich jest włączanie się w nurt podejmowanych działań, w celu zwalczania narkomanii, alkoholizmu, przeciwdziałanie chorobom społecznym, popularyzowaniu aktywnego stylu życia. Ciąg podejmowanych przedsięwzięć powiązany jest z realizacją zasady społecznej odpowiedzialności biznesu.

Jednak priorytetowe miejsce zajmuje, oferowanie produktów i usług o coraz wyższej jakości, spełniających oczekiwania potencjalnych nabywców. Jak wynika z prognoz „W pierwszej części prognozowanego okresu (lata 2016-2018) wzrost gospodarczy ustabilizuje się na relatywnie wysokim poziomie $(3,4-3,6 \%)$, napędzany głównie przez silną konsumpcję gospodarstw domowych i stabilnie rosnące inwestycje, co przyczyni się wydatnie do wzrostu wartości rynku sprzedaży aptecznej leków w Polsce.

Jednocześnie w okresie 2019-2021 oczekuje się spowolnienia gospodarczego, spowodowanego głównie przez malejącą liczbę osób aktywnych zawodowo (negatywny wpływ na konsumpcję) oraz stopniowo domykającą się unijną perspektywę budżetową na lata 2014-2021 (ujemne oddziaływanie na inwestycje), co spowoduje spowolnienie dynamiki rynku do 4,4-4,7\%" (Rynek farmaceutyczny w Polsce: wzrost $w$ tempie $5 \% \ldots)$

\section{Wykres 2. Prognozy rozwoju rynku sprzedaży aptecznej w Polsce (mld zl)} i dynamika (\%), 2016-2021

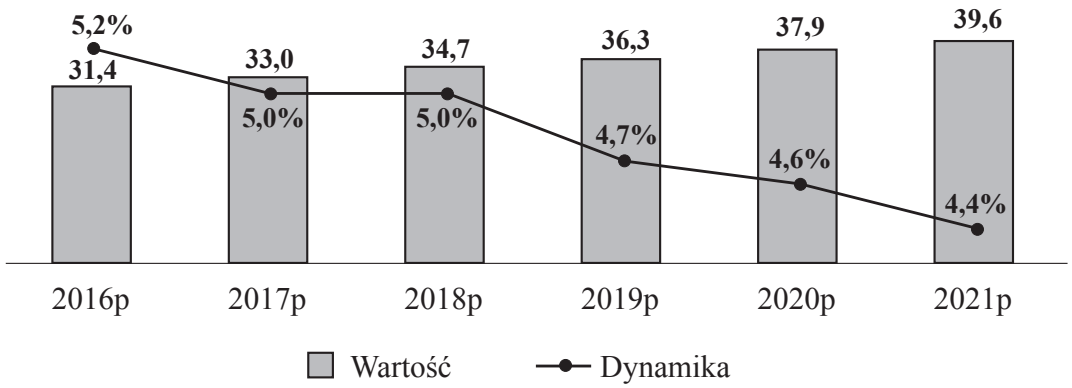

Źródlo: Rynek farmaceutyczny i ochrona zdrowia w Polsce 2016. Analiza rynku i prognoza na lata 2016-2021, PMR, 2016.

Dodatkowo czynnikiem sprzyjającym jest prowadzona przez państwo polityka w obszarze sprzedaży leków, materiałów i środków farmaceutycznych. Osoby starsze, po 75 roku życia, w Polsce będą mogły nabywać niektóre leki w formie bezpłatnej. Opracowano także nowe zasady 
refundacji leków, stworzono nową listę leków bezpłatnych i refundowanych (por. Rynek farmaceutyczny i ochrony zdrowia w Polsce 2016...). Nie bez znaczenia pozostaje także styl życia konsumentów. „Według grudniowego badania (2015 r.) Federacji Konsumentów Leki bez recepty Polacy są w czołówce UE pod względem zakupu leków i samoleczenia. Świadomość możliwości wyboru spośród konkurencyjnych wyrobów farmaceutycznych sprawia, że potencjalni nabywcy poszukują tanich i równie skutecznych produktów. Producenci zaś coraz częściej sięgają po rozwiązania wpływające skutecznie na procesy decyzyjne nabywców" (por. wykres 3).

\section{Wykres 3. Wartość sektorów reklamowych w Polsce (w mld PLN)}

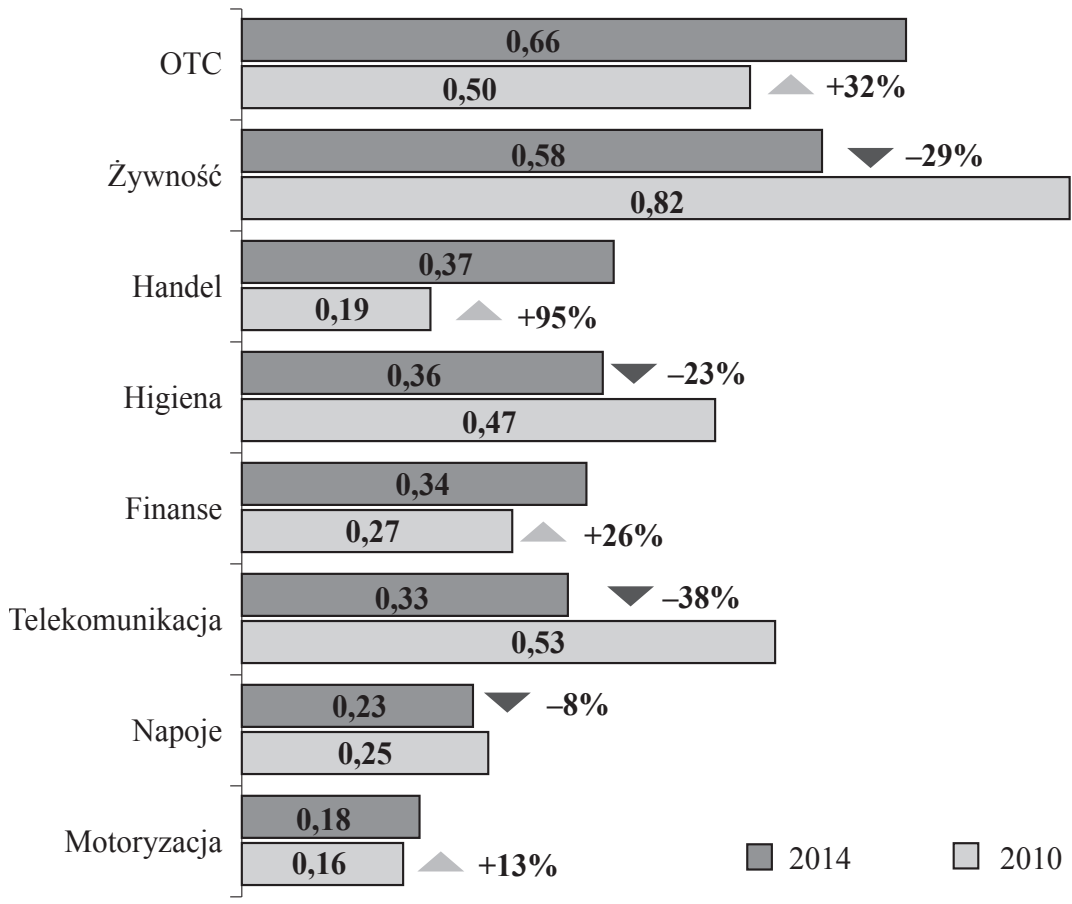

Źródło: Dane Havas Media Group, 2015, http://www.wirtualnemedia.pl/artykul/133firmy-zapewniaja-75-proc-wartosci-polskiej-reklamy-tv-caly-rynek-stracil-wskutek-cieckoncernow-analiza.

Od kilu lat wrasta ich udział w rynku reklam audiowizualnych w Polsce (por. wykres 5). 
Wykres 4. Reklama lekarstw w Polsce: najezęściej reklamowane leki w telewizji w 2015 r. (liczba reklam w tysiącach)

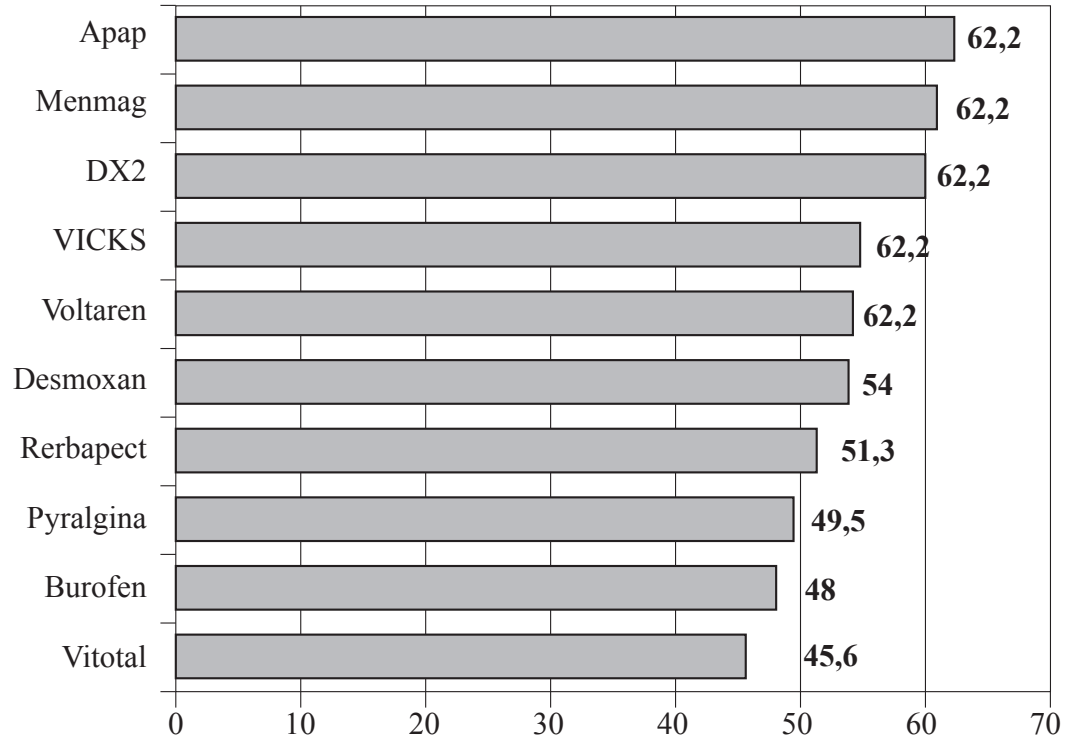

Wykres. 5 Reklama lekarstw w Polsce: wydatki brutto branży farmaceutycznej na reklamę (dane w mld zl)

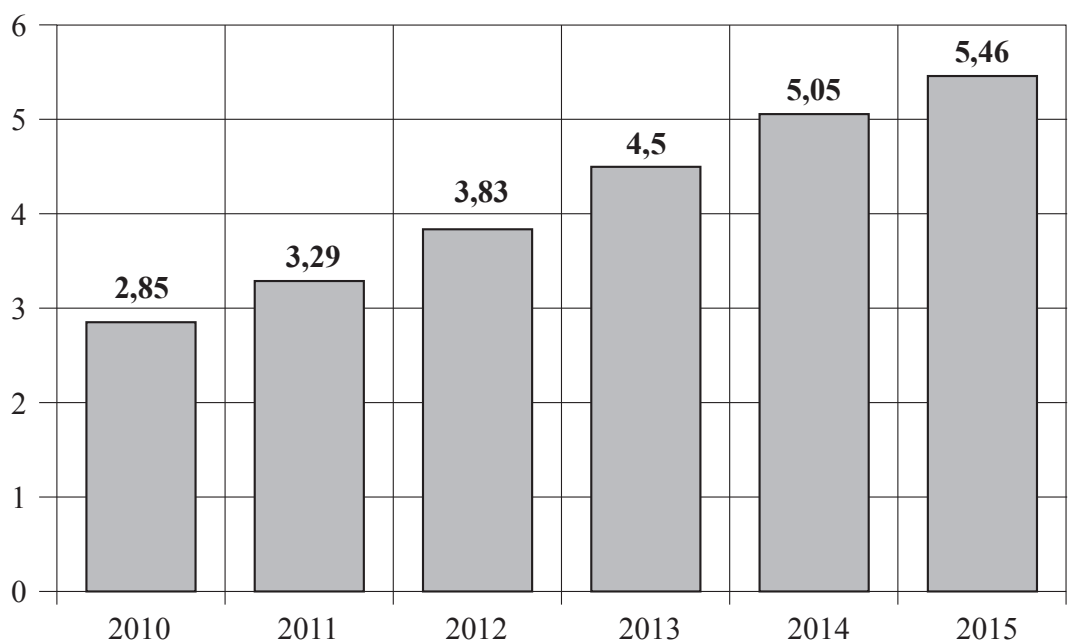

Źródło: Nielsen, Zenithoptimedia, http://wyborcza.biz/biznes/51,147743,19447593.html?i=1. 


\section{Reklama wyrobów farmaceutycznych w telewizji - wybrane przykłady}

Odwołując się do kondycji zdrowotnej, zdrowia, zdrowego stylu życia, wyglądu zewnętrznego reklamy telewizyjne wpływają na decyzje nabywców. „Oprócz produktów leczniczych reklamowane są suplementy diety, wyroby medyczne, środki spożywcze wzbogacone i środki spożywcze specjalnego przeznaczenia" (Leki a suplementy diety, 2016). Najczęściej w przekazach reklamowych oferowane są produkty przeciwzapalne, przeciwgorączkowe, przeciwbólowe, witaminy, środki na wzrost potencji. „Analizy firm, które śledzą rynek, potwierdzają, że sprzedaż danego leku i paraleku jest związana z reklamą" (Wydatki na reklamę leków rosnq na potęge). Najczęściej kampanie reklamowe realizowane są za pośrednictwem wielu nośników. Jednym z nich jest reklama telewizyjna.

Wykres 6. Udział reklam leków w stacjach telewizyjnych w latach 19972015 (TVP1, TVP2, POLSAT, TVN)

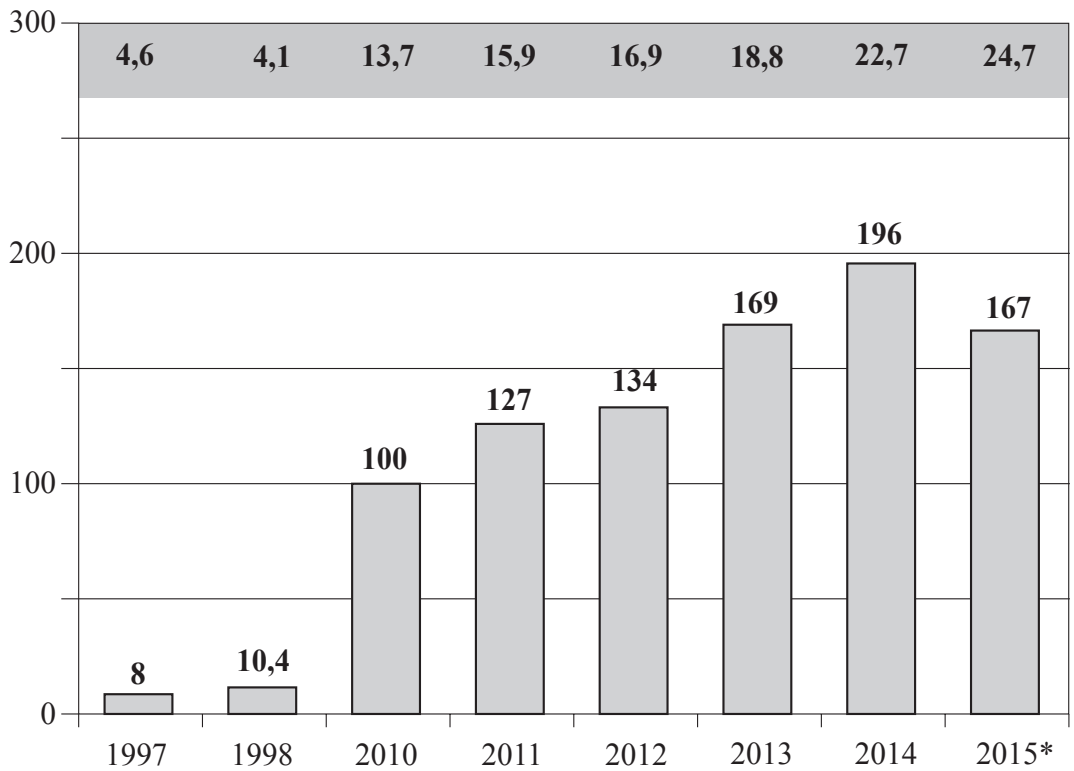

Liczba reklam w tys. $\square$ Udział reklam leków w ogólnej liczbie reklam w proc.

* dane do końca września.

Źródlo: Raport KRRiT. 
Połączenie obrazu i dźwięku sprawia, że telewizja nadal i wciąż stanowi ważne narzędzie w zakresie emisji komunikatu gospodarczego firm farmaceutycznych. O skuteczności jego oddziaływania decydują stosowane rozwiązania perswazyjne.

Najczęściej praktykowane to: postać lekarza, treść sloganu reklamowego, wnętrze pomieszczenia medycznego, odpowiednio dobrany osprzęt. Nie bez znaczenia pozostaje także kolorystyka używanych barw. Zazwyczaj dominują: biały, niebieski, pistacjowy. Ich optyczne działanie podnosi wagę przekazywanych treści.

W wielu przekazach pokazywana jest postać lekarza lub farmaceuty. Estetyka wyglądu zewnętrznego pracownika służb medycznych identyfikuje rodzaj świadczonej usługi, ale także tworzy autorytet, który z należytym rozeznaniem, wiedzą gwarantuje skuteczność działania oferowanego produktu. Medyczny osprzęt, aparatura, stanowiący wyposażenie wnętrza gabinetu, podnoszą rangę poziom wiarygodności wypowiadanego sloganu reklamowego. Autorytet w pozycji siedzącej - statycznej lub dynamicznej - przemieszczający się w kierunku widowni podaje właściwości i cechy produktu oraz skuteczność działania. Specjalista z danej dziedziny identyfikowany jest poprzez osiagnięcia naukowe, często przywoływane są tytuły naukowe. Zamieszczone w formie napisów, zwykle u dołu ekranu telewizyjnego, uwiarygodniają i stanowią desygnat autorytetu. Profesor doktor habilitowany, doktor czy magister potwierdzają wysokie kwalifikacje bohatera spotu reklamowego. Także w codziennych praktykach, mamy do czynienia z podkreśleniem wiedzy i doświadczenia osób reprezentujących branżę medyczną. „Pani/Pan Doktor”, to zwroty adresowane często do lekarzy bez względu na specjalność czy posiadane stopnie, tytuły naukowe. Natomiast w aptekach za najbardziej popularny uznać należy zwroty „Pani/Pan Magister”. Ich przeniesienie obserwujemy także w reklamie. Wątpliwości budzi jednak odwoływanie się do autorytetu nie legitymującego się podanymi kwalifikacjami wskazanego z imienia i nazwiska ${ }^{1}$. Przekazywanie tego typu treści wprowadza odbiorców w błąd i co za tym idzie, wywołuje odwrotny od zamierzonego skutek marketingowy. Przykładem nieuczciwego działania jest reklama produktów Aflofarm Fabryki Leków Sp. z. o.o. - suplementy diety o nazwach: NeoMag Cardio oraz NeoMag Forte. Aktor prezentowany, jako profesor, specjalista w zakresie chorób serca (,,profesor Jan Strzelecki - ekspert do

${ }^{1}$ Dopuszczalne jest pokazywanie osoby anonimowej, ubranej w strój właściwy dla lekarza czy farmaceuty (najczęściej biały, ale także innego koloru fartuch). 
spraw kondycji serca"), legitymujący się tytułem zawodowym dietetyka („profesor-dietetyk”), w rzeczy samej nie posiadali tego typu uprawnień. „Zdaniem Prezesa Urzędu, posłużenie się wizerunkiem specjalisty - praktyka w dziedzinie medycyny, a dodatkowo posiadającego tytuł naukowy profesora, wywołuje u konsumenta wyobrażenie, że kwestionowany suplement leku jest rekomendowany przez uznany autorytet w dziedzinie kardiologii czy dietetyki jako najlepiej działający z obecnych na rynku suplementów diety specyfików stanowiących ich substytut. Stąd należy uznać, iż posłużenie się wizerunkiem fikcyjnego specjalisty do spraw kondycji serca czy dietetyka posiadających tytuł naukowy profesora nie stanowi dozwolonej reklamy przesadnej, lecz wprowadza w błąd" (Decyzja nr RPZ 12/2011, 2011, s. 12). Urząd Ochrony Konkurencji i Konsumentów m.in. w orzeczeniu zakwalifikował przekaz jako nieuczciwy i nałożył karę finansową (Decyzja nr RPZ 12/2011..., 2011; zob. Decyzje t K/104/10..., Komisja Etyki Reklamy). Bohaterem nie musi być człowiek, bowiem z uwagi na adresata, także postaci animowane, np. Sudafed.

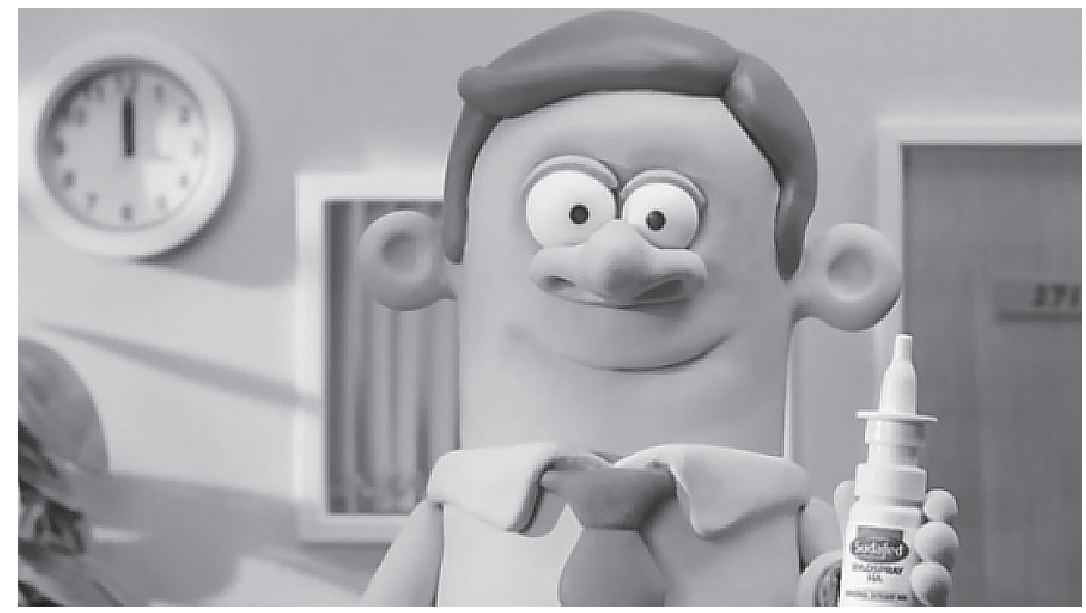

Ilustracja 1. Reklama produktu Sudafed adresowana do dzieci

Źródlo: https://www.google.pl/search?q=reklama + sudafed\&biw=1360\&bih=677\&tbm= isch\&imgil=EOaIEbs6tFWWmM\%253A\%253Bk7NKJs7Hfoxo3M\%253Bhttps $\% 25253 \mathrm{~A}$.

Skuteczność oferowanych suplementów diety zakwestionowana została także w zakresie treści sloganu reklamowego. Można przyjąć, ze slogan reklamowy, to krótka wypowiedź właściwa dla nadawcy komuni- 
katu, rozgłaszana $\mathrm{w}$ celu popularyzowania informacji o danym wyrobie, usłudze lub organizacji. Zdaniem B. Kwarciaka „Slogan jest skuteczna bronią w walce o miejsce w pamięci konsumentów; dzięki swej zwięzłości, ładunkowi emocjonalnemu i oryginalności błyskawicznie zostaje zapamiętany. W pamięci konsumentów do sloganu przyklejają się towarzyszące mu informacje, np. o marce lub produkcie" (Kwarciak, 1999). Treść sloganu może zawierać nazwę produktu, ale także może być tak skonstruowana, by cała wypowiedź reklamowa eksponowała dany wyrób bez konieczności komponowania nazwy w wypowiedzi werbalnej lektora lub w formie napisu².

Celem utrwalenia nazwy wyrobu większość producentów odwołuje się do skuteczności i efektywności działania medykamentu. Wielu konsumentom zależy, aby zażywany lek jak najszybciej przywrócił stan bezchorobowy. Stąd koncentrujemy uwagę zarówno na składnikach asortymentu, jak i procedurze działania.

Neosine $^{3}$ (syrop dla dzieci przeciwwirusowy) produkowany przez firmę Aflofarm Farmacja Polska Sp. z. o.o. - „Filip zachorował na grypę,

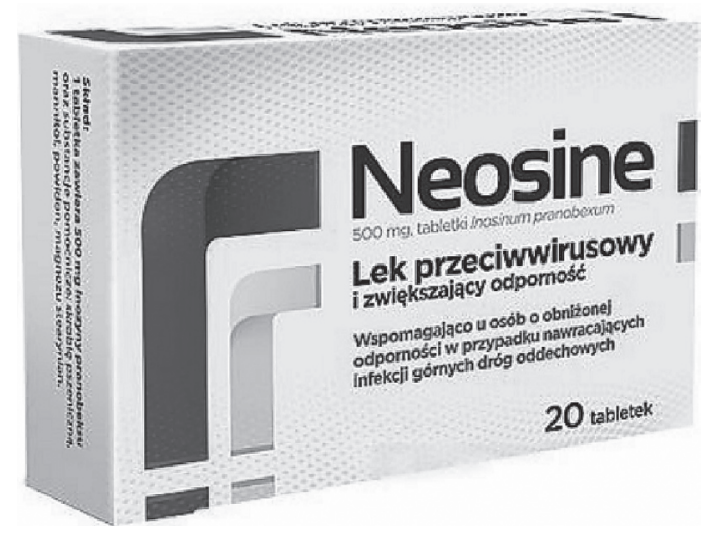

Ilustracja 2. Opakowanie Neosine

Źródło: http://www.wirtualnemedia.pl/artykul/gif-nakazal-aflofarmowi-wycofaniereklamy-tabletek-neosine.

${ }^{2}$ Samodzielne i niesamodzielne slogany to najczęściej dokonywany podział w literaturze przedmiotu.

${ }^{3}$ Slogan reklamowy w ocenie Głównego Inspektora Farmaceutycznego wprowadzał w błąd konsumentów. Wyrób nie działał przeciwwirusowo, ale ma właściwości jedynie wspomagające. Zob. Decyzja z dnia 3 marca 2016 r., znak GIF-P-450/47-9/ $\mathrm{JD} / 47-9 / \mathrm{JD} / 15$. 
a teraz zaraża swoją siostrę Olę. Mama podała obojgu Neosine - najczęściej stosowany lek przeciwwirusowy. Dzięki Neosine Ola nie zachorowała, a Filip szybciej wyzdrowiał. Do tego Neosine podniosła odporność dzieci na kolejne infekcje. Neosine - zwalcz wirusy, pokonaj infekcje" (GIF nakazat zaprzestania reklamy...), czy Neosine (tabletki) - „O tym, czy rozwinie się przeziębienie lub grypa decyduje pierwsze 48 godzin od zainfekowania wirusem. Jeśli zastosujesz w tym czasie Neosine, powstrzymasz namnażanie wirusa i nie dopuścisz do rozwoju choroby" (Decyzja z dnia 8.03.2016...).

W obu przypadkach podano skuteczność i właściwości wyrobu odmiennie od posiadanych właściwości, co w ocenie Głównego Inspektora Farmaceutycznego wprowadzało klienta w błąd.

W warstwie słownej nie można ominąc także, opisów towarzyszących wypowiedziom, najczęściej odnoszących się do skuteczności działania farmaceutyku ${ }^{4}, \mathrm{np}$ ::

- Gripex Max i Gripex HotActive Forte - ,jutro zawody”, „i sprawy szybko przyjmują właściwy obrót";

- Gripex HotActive Forte - „krótkotrwałe łagodzenie objawów przeziębienia";

- Gripex Max - „krótkotrwałe leczenie nasilonych objawów, w tym suchy kaszel" (Decyzja z dnia 26.01.2016...).
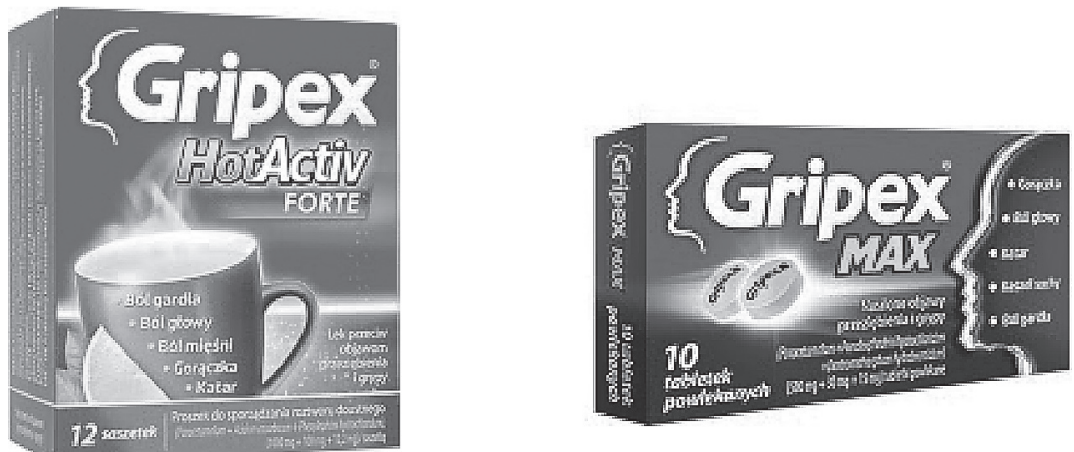

Ilustracja 3. Opakowanie Gripex Max i Gripex HotActive Forte Źródło: https://www.doz.pl/leki/p7519-Gripex_HotActiv_Forte.

${ }^{4}$ Pamiętać należy, iż art. 56 ust. 2 Prawa Farmaceutycznego, zabrania reklamy produktów leczniczych zawierających informacje niezgodne z Charakterystyką Produktu Leczniczego albo z Charakterystyką Produktu Leczniczego Weterynaryjnego. Zapis stanowi jedno ze źródeł oceny treści przekazów reklamowych, Dz. U. 2015, poz. 28. 
Preparat Ortanolu Max produkowany przez Sandoz Sp. z. o.o., jak wynika $z$ treści reklamy zawiera substancję, która silniej hamuje wydzielanie kwasu w żołądku, co powoduje, że działa dwukrotnie dłużej i jest skuteczniejszy w zwalczaniu zgagi. „Rekomenduj. Dla kogo? Dla osób stosujących niesteroidowe leki przeciwzapalne np. ibuprofen, ketoprofen. Korzyści dla pacjenta: Efekt osłonowy - zmniejsza ryzyko owrzodzenia i dokuczliwych bólów brzucha”. Wskazane korzyści, jakie winien uzyskać konsument, nie znajdują uzasadnienia w Charakterystyce Produktu Leczniczego (Decyzja z dnia 27.05.2015...).

Sudafed - „,szybka ulga dla przeziębionej głowy”, „Zablokowany nos i zatoki? Ociężała głowa? - Tak. To stan przeziębionej głowy”. W argumentacji negującej dalszą emisję tak skonstruowanej wypowiedzi gospodarczej Główny Inspektor Farmaceutyczny wskazał na brak wpisu tego typu jednostki chorobowej w literaturze medycznej (Decyzja z dnia 7.04.2015...).

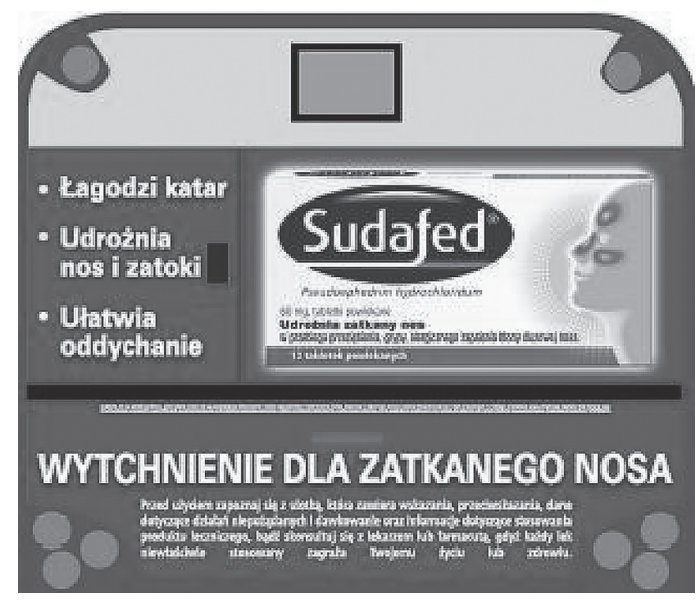

Ilustracja 4. Opakowanie Sudafedu

Źródlo: https://www.google.pl/search?q=reklama+sudafed\&espv=2\&biw=1360\&bih= $634 \&$ tbm $=$ isch\&imgil=btEMk6PzJsfmdM\%253 A\%253BXn3iwa4TgKOTDM $\% 253 \mathrm{Bhttp} \% 25253 \mathrm{~A} \% 25252 \mathrm{~F} \% 25252 \mathrm{~F}$ nowymarketing.p $1 \% 25252 \mathrm{Fa}$ $\% 25252 \mathrm{~F} 4291 \% 25252 \mathrm{Cmiedzynarodowa}-\mathrm{kampania}-\mathrm{tv}$-dla-sudafedu\&source=iu\& pf $=$ m\&fir $=$ btEMk6PzJsfmdM\%253A\%252CXn3iwa4TgKOTDM\%252C_\&usg=_LSpsofpAdplOKEGMqZ.

Odmienne w ocenie wypowiedzi, która w połączeniu z obrazem nie narusza obowiązujących norm jest „Silne i szybkie rozwiązanie na ból 
gardła”. Treść towarzysząca reklamie produktu Cholinex Intense firmy GlaxoSmithKline Consumer Health Sp. z. o.o., mimo początkowych zastrzeżeń, uznana została za prawidłowo skonstruowaną (Decyzja z dnia 7.07.2015).

Pojawiające się w komunikatach niektórych nadawców gwiazdki, jako ewentualne źródła dodatkowej, uzupełniającej wiedzy odbiorców reklamy nie zawsze są odczytywane przez adresatów informacji.

Tło, otoczenie nie pozostaje bez wpływu na poziom akceptacji nabywców. To kolejny ważny czynnik składowy komunikatu perswazyjnego. Warstwa wizualna miała znaczenie w spocie Gripex HotActive Forte i Gripex Max. Skuteczność działania zobrazowano w następujący sposób:

- „bohaterowie przyjmują lek po południu, gdy już zmierzcha (ciemna ponura sceneria): zawody odbywają się nazajutrz w ciągu dnia (jasna sceneria, silne światło słoneczne);

- w pierwszej części, w której bohaterowie sięgają po leki, pogoda jest zdecydowanie inna, świeci słońce - tak wyraźna zmiana warunków atmosferycznych wymaga długiego upływu czasu;

- na początku spotu, w dniu treningu, bohaterowie są ubrani w szare kombinezony przeznaczone do jazdy próbnej; pod koniec reklamy w dniu zawodów uczestnicy mają oficjalne biało-czerwone kombinezony przeznaczone do startu w amatorskim rajdzie" (Decyzja z dnia 26.01.2016...).

Ciemne kolory, np. czarny, szary, burgundowy symbolizują zły nastrój, stan zagrożenia chorobowego, chorobę i przeciwnie jasne barwy, żółty, niebieski, biały, pomarańczowy skuteczne działanie rekomendowanego produktu. Obraz zawierający przekaz określonej treści będzie właściwie odczytany tylko wówczas gdy, jako widzowie dysponujemy wiedzą, ,[...] odczuciami i warunkami, w których dokonuje się odbiór (przekaz / widz = znaczenie)" (Lewis, 1991, s. 18). Posługując się symbolami musimy zwrócić także uwagę na to, że „znak istnieje w odniesieniu do widza”, w przeciwnym razie ,[...] jest jak drzewo, które pada w niezamieszkałym lesie - istnieje tylko na poziomie, który wyznacza jego twórca" (Lewis, 1991, s. 9).

Podkreślić należy, że w analizowanych przykładach nigdy pierwszoplanowej roli nie przypisano pojęciu zdrowia czy zdrowiu. Potrzebę dbałości o nie ukazywano poprzez negatywne następstwa braku zakupu stosownego medykamentu. 


\section{Podsumowanie}

Skuteczność kampanii reklamowych zobowiązuje do poszukiwania nowych skutecznych narzędzi oddziaływania. Umiejętność zarządzania wymaga nieustannego analizowania otoczenia, zmieniających się preferencji konsumentów. W ostatnich latach coraz częściej obserwujemy instrumentalne wykorzystanie wartości. Poprzez połączenie z rekomendowanym towarem podnoszą jego atrakcyjność. Pozytywne nastawienie nabywcy, wynikające $\mathrm{z}$ oceny cech i właściwości asortymentu odwołujących się do hierarchii wartości jednostki, sprawia, że prozakupowy proces decyzyjny konsumenta przebiega niejednokrotnie zgodnie z oczekiwaniami nadawcy przekazu. „Bezinwazyjny” sposób ingerowania $\mathrm{w}$ proces decyzyjny nabywcy pozwala na dokonywanie wyborów właściwych dla systemu wartości. „Stąd zasadniczy mechanizm zachowania się człowieka można opisać według następującego schematu:

- człowiek rozpoznaje (doznaje) pewne swoje stany lub relacje do innych jako cenne dla niego oraz;

- uznaje przez analogię pewne stany cudze jako cenne dla innych;

- dokonuje wyboru między różnymi rzeczami uznanymi lub rozpoznanymi jako cenne;

- dąży do poznania tego, co rozpoznaje jako cenne dla siebie oraz;

- dąży do wcielenia (zrealizowania) tego, co uznaje za cenne dla innych" (Grzegorczyk, 1989, s. 51).

Mimo wielu narzędzi komunikacji, reklama telewizyjna zajmuje ważne miejsce w rekomendowaniu wyrobów farmaceutycznych. Ładunek perswazyjny przekazu audiowizualnego wywiera większy wpływ na szczególnego adresata przekazu, jakim jest konsument, którego poziom analizy treści jest obniżony z uwagi na stan chorobowy. Jak słusznie zauważa M. McLuhan owe nośniki treści inspirujące nas do działania określa jako ,[...] pigułki, które działają na podświadomość i rzucają na ludzi [...] hipnotyczny czar" (McLuhan, 1975, s. 121). Linearność wartości preferowanych przez jednostkę z nadawcą komunikatu może mieć wyraźny wpływ na efektywność prowadzonej kampanii. Natomiast przekroczenie granic normatywnych i pozanormatywnych może wpłynąć negatywnie nie tylko na sprzedaż i popularność produktu, ale również wizerunek firmy. 


\section{Bibliografia}

Armstrong M. (1998), Zarzadzanie zasobami ludzkimi. Strategia i działania, Wydawnictwo Profesjonalnej Szkoły Biznesu, Kraków.

Barańska M. (2012), Polityka ograniczenia reklamy w Polskiej Telewizji. Studium politologiczno-prawne, Wydawnictwo UAM, Poznań.

Barańska M. (2013), Ochrona zdrowia jako element polityki publicznej, „Środkowoeuropejskie Studia Politologiczne", nr 2, Poznań.

Blanchard K., O’Connor M. (1998), Zarzadzanie poprzez wartości, Studio EMKA, Warszawa.

Bocheński J. M. (1992), Sto zabobonów, Wydawnictwo Philed, Kraków.

Covey S. R. (1989), 7 nawyków skutecznego działania, Wydawnictwo Medium, Warszawa.

Decyzja nr RPZ 12/2011 (2011), Urząd Ochrony Konkurencji i Konsumentów, Poznań, https://uokik.gov.pl/download.php?plik=10382.

Decyzja z dnia 7.07.2015, znak: GIF-P-R-450/78-4/JD/14, https://www.gif.gov.pl/ download/1/5403/REK2015-07-07.pdf.

Decyzja z dnia 8.03.2016, znak: GIF-P-R-450/48-8/JD/15, https://www.gif.gov.pl/ download/1/5522/REK2016-03-08.pdf.

Decyzja z dnia 26.01.2016, znak: GIF-P-R-450/44-3/JD/15, https://www.gif.gov.pl/ download/1/5509/REK2016-01-26.pdf.

Decyzja z dnia 27.05.2015, znak: GIF-P-R-450/15-3/JD/15, https://www.gif.gov.pl/ download/1/5367/REK2015-05-27.pdf.

Decyzja z dnia 7.04.2015, znak: GIF-P-R-450/75-4/JD/14, https://www.gif.gov.pl/ download/1/5327/REK2015-04-07.pdf.

Decyzje t K/104/10, Komisja Etyki Reklamy.

Dobiegała-Korona B. (2012), Nowa rola marketingu w budowie wartości przedsiębiorstwa, „Kwartalnik Nauk o Przedsiębiorstwie”, nr 2, Warszawa.

Doyle P. (2008), Value-Based Marketing. Marketing Strategies for Corporate Growth and Shareholder Value, $2^{\text {nd }}$ edition, John Wiley \& Sons, Chichester.

GIF nakazat zaprzestania reklamy telewizyjnej syropu dla dzieci Neosine, „Gazeta Prawna", 7.03.2016, http://serwisy.gazetaprawna.pl/zdrowie/artykuly /926337, gif-nakazal-zaprzestania-reklamy-telewizyjnej-syropu-dla-dziecineosine.html.

Gołaszewska M. (1994), Hipotetyczna wartość wartości, w: Neotyczny wymiar osobowości, red. K. Popielski, Wydawnictwo KUL, Lublin.

Gordon I. G. (2001), Relacje z klientem. Marketing partnerski, PWE, Warszawa.

Galtung J. (1994), Menschenrechte-Anders gesehen, Frankfurt a. Main.

Jagdish S. N., Newman B. A., Gross B. L. (1991), Consumption Values and Market Choices: Theory and Applications, South - Publishing Co, Cincinnatti.

Kant E. (1972), Krytyka rozumu praktycznego, przekład J. Gałecki, Wydawnictwo PWN, Warszawa. 
Karney J. E. (1998), Człowiek i praca. Wybrane zagadnienia z psychologii i pedagogiki pracy, Międzynarodowa Szkoła Menadżerów, Warszawa.

Karta praw podstawowych Unii Europejskiej, Dz. Urz. UE 2012/C 326/02.

Konstytucja Rzeczypospolitej Polskiej z dnia 2 kwietnia 1997 r. uchwalona przez Zgromadzenie Narodowe w dniu 2 kwietnia 1997 r., przyjęta przez Naród w referendum konstytucyjnym w dniu 25 maja 1997 r., podpisana przez Prezydenta Rzeczypospolitej Polskiej w dniu 16 lipca 1997 r., Dz. U. 1997, $\mathrm{Nr} 78$, poz. 483.

Konwencja o Ochronie Praw Człowieka i Podstawowych Wolności sporządzona w Rzymie dnia 4 listopada 1950 r., zmieniona następnie Protokołami nr 3, 5 i 8 oraz uzupełniona Protokołem nr 2, Dz. U. 1993, Nr 61, poz. 284.

Kowalczyk S. (1979), Podstawy światopogladu chrześcijańskiego, „Studia Płockie”, t. IX/1981, ODISS, Warszawa.

Kwarciak B. (1999), Co trzeba wiedzieć o reklamie, Wydawnictwo Profesjonalnej Szkoły Biznesu, Kraków.

Leki a suplementy diety $w$ reklamach (2016), Raport KRRiT, Warszawa, http:// www.krrit.gov.pl/krrit/aktualnosci/news, 2265,leki-a-suplementy-diety-wreklamach.html.

Lewis J. (1991), The Ideological Octopus: An Exploration of Television and Its Audience (Studies in Culture and Communication), Routledge, New York.

Lucewicz J. (2000), Rola kultury organizacyjnej w zarzqdzaniu kadrami, w: Zarzqdzania kadrami. Podstawy teoretyczne i ćwiczenia, red. T. Listwana, Wydawnictwo AE, Wrocław.

McLuhan M. (1975), Przekaźnik, czyli przedlużenie człowieka, w: Wybór pism, thum. K. Jakubowicz, Warszawa.

Melosik Z. (2003), Kultura popularna jako czynnik socjalizacji, w: Pedagogika. Podręcznik akademicki, red. Z. Kwieciński, B. Śliwerski, t. II, Wydawnictwo PWN, Warszawa.

Otto J. (2001), Marketing relacji. Koncepcja i stosowanie, Wydawnictwo C.H. Beck, Warszawa.

Owsiak W., Popielski K. (2008), Noetyczne uwarunkowania strategii korzystania z telewizji, w: Wartości dla życia, red. K. Popielski, Wydawnictwo KUL, Lublin.

Popielski K. (red.) (1994), Neotyczny wymiar osobowości, Wydawnictwo KUL, Lublin.

Prymon M. (2008), Kategoria wartości w perspektywie nauk menedżerskich, w: Wartości dla życia, red. K. Popielski, Wydawnictwo KUL, Lublin.

Rogoziński K. (2006), Wpisanie relacji w marketingowy kontekst, w: Zarzqdzanie relacjami w ustugach, red. K. Rogoziński, Wydawnictwo Difin, Warszawa.

Rokeach M. (1979), Understanding Human Values, The Free Press, New York.

Rynek farmaceutyczny i ochrony zdrowia w Polsce 2016. Analiza rynku i prognozy rozwoju na lata 2016-2021, http:/www.pmrpublications.com/product/Rynek-farmaceutyczny-i-ochrony-zdrowia-w-Polsce-2016. 
Rynek farmaceutyczny w Polsce: wzrost $w$ tempie 5\% w latach 2016-2021, http:// www.ceepharma.com/analysis/1195/rynek-farmaceutyczny-w-polscewzrost-w-tempie-5-w-latach-2016-2021.

Stownik łacińsko-polski (1982), red. H. Mengego, H. Kopii, oprac. K. Komanieckiego, Olsztyn.

Strona internetowa Helsińskiej Fundacji Praw Człowieka, www.hfhr.org.pl.

Tatarkiewicz W. (1976), Pararega, Wydawnictwo PWN, Warszawa.

Traktat o Unii Europejskiej - tekst skonsolidowany uwzględniający zmiany wprowadzone Traktatem z Lizbony, Dz. U. 2004 Nr 90, poz. 864.

Wartości i zaufanie społeczne w Polsce w 2015 r. (2015), Główny Urząd Statystyczny, Warszawa.

Wydatki na reklame leków rosna na potegę, http://wyborcza.biz/biznes/1,147743,19447593,wydatki-na-reklame-lekow-rosna-na-potege.html.

Zdrowie i zdrowy styl życia w Polsce (2007), Badania Centrum Badania Opinii Społecznej, BS/138/2007, Warszawa.

\section{Managing the value of health in marketing on the example of selected advertisements of pharmaceutical corporations}

\section{Summary}

The paper addresses the issue of managing the value of health in marketing. The author undertakes to analyze this issue with respect to selected advertisements of pharmaceutical corporations and applies the needs theory, among other things. She observes that the persuasive content of audiovisual messages concerning pharmaceuticals has a greater impact on a particular sector of the target of these messages, namely those consumers whose ability to analyze this content is corrupted due to their illness.

The author concludes by saying that the efficiency of advertising campaigns demands new and efficient instruments of influencing. Skilful management calls for continual analyzing of the environment and changing consumer preferences. Recently, we have seen that different values have been instrumentally used. Combined with the recommended commodities they make them more attractive.

Key words: health value, advertisement, marketing, pharmaceutical companies 